\title{
The twelve theses: a call to a new reformation
}

\author{
As doze teses: chamada para uma nova reforma
}

\begin{abstract}
With every discovery emerging from the world of science over the last 500 years concerning the origins of the universe and of life itself, the traditional explanations offered by the Christian Church appeared to be more and more dated and irrelevant. Christian leaders, unable to embrace the knowledge revolution seemed to believe that the only way to save Christianity was not to disturb the old patterns either by listening to, much less by entertaining the new knowledge. I tried to articulate this challenge in a book entitled: Why Christianity Must Change or Die, published in 1998. In that book I examined in detail the issues that I was convinced Christianity must address. Shortly after that book was published I reduced its content to twelve theses, which I attached in Luther-like fashion to the great doors on the Chapel of Mansfield College at Oxford University in the United Kingdom. I then mailed copies of those Twelve Theses to every acknowledged Christian leader of the world. It was an attempt to call them into a debate on the real issues that I was certain the Christian Church now faced. I framed my twelve theses in the boldest, most provocative language possible, designed primarily to elicit response and debate. I welcome responses from Christians everywhere. I claim no expertise or certainty in developing answers, but I am quite confident that I do understand the problems we are facing as Christians who are seeking to relate to the $21^{\text {st }}$ century.
\end{abstract}

Keywords: Theology Christian, New reformation, Christianity, The future of Christianity

\section{Resumo}

Para cada descoberta que surgiu no mundo da ciência, ao longo dos últimos 500 anos, sobre as origens do universo e da vida, as explicações tradicionais oferecidas pela Igreja Cristã pareciam cada vez mais antiquadas e irrelevantes. Os líderes cristãos, impossibilitados de acolher a revolução do conhecimento, pareciam acreditar que a única maneira de salvar o cristianismo era não mudar os velhos padrões, seja por não ouvir, e muito menos se entreter com o novo conhecimento. Tentei articular este desafio em um livro intitulado: Why Christianity Must Change or Die (Por que o cristianismo deve mudar ou morrer), publicado em 1998. Nesse livro examinei detalhadamente as questões que o cristianismo deveria abordar. Pouco depois que o livro foi publicado, reduzi o seu conteúdo para doze teses e, como Lutero, afixei-as nas grandes portas da Capela de Mansfield College, da Universidade de Oxford, no Reino Unido. Enviei também cópias dessas "Doze teses" para cada líder cristão reconhecido do mundo. Foi uma tentativa de chamá-los para um debate sobre as questões reais que, na minha visão, têm confrontado a Igreja Cristã hoje. Expressei essas doze teses na mais ousada linguagem possível, provocando resposta e debate. São bem-vindas e aguardadas as respostas que recebo dos cristãos de todos os lugares. Não reivindico nenhuma expertise ou certeza no desenvolvimento das respostas, mas estou bastante confiante de que entendo os problemas que enfrentamos como cristãos que buscam se relacionar com o século 21.

Palavras-chave: Teologia cristã, Nova reforma, Cristianismo, Futuro do Cristianismo

Article received on October 10, 2014. Approved on March 20, 2015.

\footnotetext{
* Master in Theology. A retired American bishop of the Episcopal Church (Episcopal Diocese of Newark). Country of origin: USA. E-mail: CMSCTM@aol.com
} 


\section{Introduction}

As the 21st century approached with millennial celebrations, I felt myself increasingly compelled to assess the state of the Christian religion throughout the world. There were multiple signs everywhere of its decline and perhaps even of its imminent death. Fewer and fewer people were attending European churches and those that did were rapidly aging. North American churches were breaking into either a vapid, liberal emptiness or a religious, anti-intellectual fundamentalism. South American Churches were increasingly becoming separated from the concerns of the people and no leaders seemed capable of speaking to those concerns with authority. None of these patterns were new. With every discovery emerging from the world of science over the last 500 years concerning the origins of the universe and of life itself, the traditional explanations offered by the Christian Church appeared to be more and more dated and irrelevant. Christian leaders, unable to embrace the knowledge revolution seemed to believe that the only way to save Christianity was not to disturb the old patterns either by listening to, much less by entertaining the new knowledge

As I engaged these issues as a bishop and a committed Christian, I became convinced that the only way to save Christianity as a force in the future was to find within the church the courage that would enable it to give up many of the patterns of the past. I tried to articulate this challenge in a book entitled: Why Christianity Must Change or Die (1998), published just before the dawn of the $21^{\text {st }}$ century. In that book I examined in detail the issues that I was convinced Christianity must address.

Shortly after that book was published I reduced its content to twelve theses, which I attached in Luther-like fashion to the great doors on the Chapel of Mansfield College at Oxford University in the United Kingdom. I then mailed copies of those Twelve Theses to every acknowledged Christian leader of the world, including the Pope, the Patriarch of Eastern Orthodoxy, the Archbishop of 
Canterbury, the leaders of the World Council of Churches, the denominational leaders of the major Protestant churches in both the United States and Europe and the well-known television voices of Evangelical Christianity. It was an attempt to call them into a debate on the real issues that I was certain the Christian Church now faced. I framed my twelve theses in the boldest, most provocative language possible, designed primarily to elicit response and debate.

Recently, the editors of the Journal Horizonte requested that I explicate for their publication in Latin America, throughout the Spanish-speaking world and ultimately to Christians everywhere in the world, my reasons for calling for debate on these twelve theses. I am pleased to have the opportunity to do just that. I welcome responses from Christians everywhere. I claim no expertise or certainty in developing answers, but I am quite confident that I do understand the problems we are facing as Christians who are seeking to relate to the $21^{\text {st }}$ century.

\section{Thesis n. 1}

"Theism as a way of defining God is dead. God can no longer be understood with credibility as a being, supernatural in power, living above the sky and prepared to invade human history periodically to enforce the divine will." So most theological God-talk today is meaningless. We must find a new way to conceptualize and to speak about God.”

Since this thesis is crucial to all of the others, I will spend a longer period of time and fill more space addressing it than any of the others. It is important that Christian people acknowledge the crisis of faith in which we live, to understand the sources from whence this crisis has come and to recognize why it can neither be denied nor ignored.

The person who, in my opinion, initiated the new view of reality, which is today challenging the credibility of the way we have traditionally articulated the concepts of Christian understanding, was a devout Polish monk named Nicolaus 
Copernicus, who lived as long ago as the $16^{\text {th }}$ century. Few people at that time, however, were aware of either Copernicus' discoveries or of his conclusions, so he died without ever really challenging the consciousness of the Church. No one grasped the depth of the revolution that he had inaugurated and so it was that in his death he was embraced in the bosom of Mother Church.

Copernicus' immediate intellectual descendant, however, was a $17^{\text {th }}$ century Italian astronomer named Galilei Galileo, who, like Copernicus, was a deeply committed Catholic. Not only was Galileo's daughter a nun, but he was himself well known and trusted in top Vatican circles. He was a genuine friend of the one who at that time served as the Pope sitting on the throne of Peter. Galileo had constructed his own telescope and, like Copernicus, he studied the movement of the heavenly bodies, always seeking to understand their relationship with one another and with the planet Earth. Copernicus' theory of the location of the sun at the center of the universe was a concept about which Galileo had become convinced. The earth's relationship to that central sun, Copernicus was certain even though it seemed radical and revolutionary, was that of its satellite rotating around it on an annual basis. This hypothesis fitted Galileo's own conclusions and it answered many of his questions causing him, slowly but surely, to embrace what later would come to be named "the Copernican revolution." Galileo, however, unlike Copernicus, was not a cloistered man. He was a well-known scientist and a very public figure. It did not occur to him to refrain from either writing about or publicizing his findings. Proceeding to do just that, he soon discovered that his writing was creating conversations and controversies that would inevitably bring him into direct conflict with the hierarchy of the Catholic Church. At that time in history, the Church was still a very powerful, political force in the world. Its power was located in its widely accepted claim that it had the authority to speak for God. This meant that the leaders of the Catholic Church had both a political need and a self-serving desire to control thought, to define truth and to interpret reality for all people. Doubt from any corner that seemed to erode that part of the Church's role would surely challenge this authority. 
The truth possessed and preserved by the Church was said to have been received as the result of divine revelation. People had been taught to believe that this truth had not only been revealed in Jesus Christ, but that it had also been worked out in terms of what they were quite sure was an undoubted and even undoubtable cosmology. This cosmology could be simply stated: God dwelt above the sky. The earth was the center, not only of the universe, but also of God's attention. The all-seeing divine view of the world from the realm of heaven assisted God in the task of recording all of the deeds and misdeeds of each human life. Record books were kept on human behavior and these record books formed the basis upon which each human life at the end of time would be judged. That was also the moment when the eternal destiny of that person would be determined. The Church and its faith system thus served as an incredibly powerful controller of human behavior. That, in essence, was what both Copernicus and Galileo appeared to challenge directly. It was a challenge not only to perceived truth, but also to political power. It could not be ignored. Galileo was thus charged with heresy. Ultimately he was convicted of that charge. The normal punishment for heresy at that time was death by fire, that is, the heretic would be burned at the stake.

Galileo's trial was quite public. His well-distributed and well-documented views were not only attacked vigorously, but they were also ridiculed by the ecclesiastical leaders of this inquiry. The accusation was that Galileo's views were contrary to the "Word of God," as revealed in the sacred scriptures, which were believed at that time to be the literal and dictated words of God. If Galileo was right, both the Bible and the Church were wrong. That was the stated ecclesiastical conclusion that sealed Galileo's fate. On almost every page of the Bible was a narrative stating that God lived above the sky in the upper tier of a three-tiered universe. God sent the rain from the sky at the time of Noah and the flood (Gen. 7). In the book of Genesis the people sought to build the Tower of Babel so tall that it would reach into the sky where God was believed to live (Gen. 13). In the Patriarch Jacob's dream he was said to have seen a ladder connecting heaven above with the earth below and on the ladder connecting the two there were angels descending and ascending (Gen. 28). Moses was said to have received the Torah from God, 
who came down from heaven above the sky to the top of Mount Sinai to hand those tablets of stone containing the Ten Commandments directly to Moses (Ex. 20). In the book of Joshua, Moses' successor had implored God to stop the sun in the sky from rotating around the earth so that his army could have more daylight time in which to destroy his enemies during the rigors of battle (Josh. 10). Elijah was carried into the sky, the realm of God, by a magical fiery chariot drawn by magical fiery horses and he was propelled heavenward by a God-sent mighty whirlwind (II Ki. 2), which came out of the sky.

These biblical assumptions supporting the idea that God lived above the sky were not just limited to what Christians called the Old Testament. When Jesus was born, according to the Gospel of Matthew, God hung out a new star in the sky to announce his birth (Matt. 1). The author of the Gospel of Luke had written that angels from heaven broke through the darkness of the midnight sky to sing of his arrival to hillside shepherds (Luke 2). Later it was said that Jesus ascended into the sky above the earth to be with God (Acts 1). Every part of the Bible assumed that the earth was the center of a three-tiered universe. Galileo had challenged this ancient and universally accepted world view and, in the process, had destabilized this well-established, traditional wisdom. He had reordered the shape of the universe. Galileo's insight displaced God from God's dwelling place and ultimately, it would render God homeless. If God did not dwell above the sky where was God? Human beings could not imagine God living anywhere else. Galileo's thought, therefore, rocked the foundations of the Christian worldview. Not surprisingly, in the trial Galileo was found guilty of heresy. He was sentenced to be burned at the stake. Because of his advanced age and his poor health, however, and aided by his close connections in high places in the Vatican, a plea bargain was arranged. On Galileo's part he agreed to renounce his own conclusions and to admit publicly that he had been wrong. He also agreed not to publish his ideas ever again in any medium of communication. Finally, he accepted the imposed sentence of house arrest for the balance of his life. With these rather drastic concessions, his life was spared by the Vatican tribunal. The crisis had been averted, or at least the 
ecclesiastical leaders thought so. Truth, however, cannot be dismissed simply because it is inconvenient and Galileo's insights had truth on their side. In December of 1991 the Vatican finally announced that it now believed that Galileo was correct. By that time space travel had begun. The study of astronomy and astrophysics had exploded. The Hubble telescope had been invented and the vastness of the universe was beginning to make its impact on the human consciousness in undeniable ways. The result of this controversy around Galileo was that God had been permanently displaced. The old definition about the shape of the world and the concept of God attached to that world began to fade. The new definitions were still unformed, still hard to understand both intellectually and emotionally. Christianity and its authority, however, began to wobble perceptibly. That wobble was destined to grow in intensity far beyond that moment, as insights from other intellectual disciplines began to surge into the human consciousness. Galileo had forced the world into a period of rapid change and growth and with all these changes cascading into consciousness; it soon became obvious that Christianity, as it had been traditionally understood, no longer fitted very comfortably into the world that was being born.

In the year that Galileo died, Isaac Newton was born in the county of Northumbria in the country of England. Newton was primarily a mathematician, but mathematics pushed him ultimately into a completely new understanding of how both the universe and the world operated. He studied causation, gravity and the interrelatedness of all living things. There was no room in Newton's universe for an external God who would intervene supernaturally into human history. The arena in which those things we called "miracles" was believed to operate began to shrink perceptibly. It would not be long before the concept of "miracle" would begin to disappear altogether from the human vocabulary and ultimately from our expectations. Many areas of life felt this impact.

Once human beings began to understand something about weather fronts and what caused them and other geological realities, then God was no longer believed to control things like hurricanes, floods, droughts and earthquakes. No 
longer did anyone think that these natural events were instruments of God's wrath or the divine method of punishing people for their sins. Human beings now explained these acts as natural, as being caused by such things as low pressure systems travelling across warm ocean waters, or the shift of tectonic plates far beneath the surface of the earth. God, removed from the sky by Galileo, was now beginning to be separated from any role in the patterns of the weather. In this moment the idea of God as a being, external to this world, yet willing and able to invade this world, began to be in full-scale retreat. Suddenly human beings did not understand any longer why an external being called God was needed or just what it was that God did. The traumas in the traditional concept of God would continue to be felt as the knowledge explosion continued to break in upon us from other sources. Now God was not just homeless, but increasingly, God was becoming unemployed. God no longer had any work to do.

In the 1830's an English naturalist named Charles Darwin began his voyage around the world on the ship, HMS Beagle. This trip would reach its climax in the Galapagos Islands off the cost of Ecuador in South America, where Darwin would find unequivocal evidence that the evolution of species is caused by the interaction of living things with a changing environment. In 1859 Darwin published his findings in a book entitled The Origin of Species by Means of Natural Selection (DARWIN, 1859). A few years later he would follow this book with another called The Descent of Man (DARWIN, 1871). In those two volumes Darwin would maintain that all life evolved over millions, even billions of years from a single cell; that all life was thus connected; that no species was stable, but was always in flux; that human life arose out of the primate family, and that the story of creation in the book of Genesis was neither biologically nor historically accurate. It began to be apparent in human knowledge that human life was not in any literal sense created in the image of God, so much as God had been created in the image of humanity. It also became increasingly obvious that human beings were not just a little lower than the angels, as the book of Psalms had suggested (Ps. 8), but that we were, in fact, just a little higher than the apes. All of these things resulted in disturbing, 
frightening and much resisted insights, but their truth would be confirmed over and over again in subsequent years and is, at least in intellectual circles, completely accepted truth today.

Later, in that same $19^{\text {th }}$ century a French doctor named Louis Pasteur discovered germs and with that discovery the practice of modern medicine began to emerge. Sickness at one time had been believed to be in the domain of God alone. It was, therefore, treated with prayer and sacrifices designed to encourage God to put an end to what was believed to be divine punishment. As germs, viruses, coronary occlusions, tumors and various leukemias came to be understood, treatment changed from prayer and sacrifice to antibiotics, surgery, chemotherapy radiation and preventive measures associated with diet and exercise. Once again, the God who was understood as an external being, supernatural, invasive and miraculous, was separated from another area of human life and, in the process, medicine became increasingly secularized and with great rapidity the theistic concept of God began to move toward the backwaters of life and human awareness.

In the early $20^{\text {th }}$ century a German doctor named Sigmund Freud began to probe the human mind with his study into the nature of the unconscious, the emotions and the inner workings of what we once called "the soul." In the process, Freud helped to usher into Western thought a whole new understanding of human life. So many of the symbols that once stood at the core of the Christian story now looked very different when analyzed from a Freudian perspective. Was "the Father God" in heaven merely a projection of human parental authority into the sky? Was the power of guilt, on which so much of the Christian life had been based, anything more than a method of human behavior control? These powerful guilt forces had also been projected into the afterlife of either eternal bliss or eternal flames, but now quite suddenly they appeared to be not the result of divine revelation, but of psychic disorder. God, understood as the judge, began to be recognized as one way that we human beings dealt with our own lack of self-worth and mental health. The fear of God, which informs so much of Christianity with its images of heaven and 
hell, began to disappear. The retreat of God into irrelevance in the face of new knowledge was all but complete.

In the latter years of the $20^{\text {th }}$ century a German physicist named Albert Einstiein, who spent much of his adult life at Princeton University in New Jersey, began to study what came to be called "relativity." Time and space were discovered not to be infinite, but finite, and always relative to each other. Since human life is lived in time and space, it also is lived in relativity. Everything we say and do is said and done in the relativity of time and space. This means that there is no such thing as absolute truth. Even if there were something called absolute truth, it would be incapable of being known or articulated inside human experience. With this insight all religious claims to objectivity disappeared. There is no such thing as the "one true religion" or the "one true church." There is no such thing as an infallible pope or an inerrant Bible. There is no such thing as an eternal creed or a particular doctrine that can be defined as truth for all time. Human life is lived, rather, in a sea of relativity. Life is an unending journey into whatever is ultimately real, but no one, who is bound in time, can ever fully know it or embrace it. The Christian Church thus can never offer the security of certainty to anyone. No human institution, including the Church, can or does possess eternal truth. All human beings and all human institutions can, in Paul's words, only see through a glass darkly (II Cor. 15).

This ever so brief, and therefore, inadequate chronicle of the human expression of knowledge from the $16^{\text {th }}$ century until today, makes us aware, that at the very least, the way human beings have conceptualized God in the past has now been fundamentally altered. Yet in the liturgies of all Christian Churches we continue to use these intellectually dismissed concepts of the past, as the template against which liturgy is constructed. So we still say: "Our Father, who art in heaven." That prayer is one addressed to a God understood as a being, supernatural in power, who dwells above the sky of a three-tiered universe and who in some sense is still believed to control our world. To this God we still ask for "our 
daily bread," for the establishment of the reign of God on earth, for forgiveness and guidance. We still approach this God, understood as a judge, on our knees, begging for mercy, asking for favors and searching for healing. When tragedy strikes we still wonder why and we still ask if this tragedy is a reflection of the desires of God that we be "punished for our sins." "What have I done to deserve this?" we say.

We call this understanding of God "theism." We say that those who do not believe in this theistic God must be "a - theists." Is it not, however, the theistic definition of God rather than the reality of God, that is the problem? Theism, as a way of understanding God is now the victim of our expanded knowledge. That definition no longer makes sense in our world. There is no supernatural deity above the sky waiting to come to our aid. Space is infinite and we human beings now embrace its infinity. Theistic talk is, therefore, meaningless. Does this mean, however, that God is meaningless? That is the major issue before the Christian Church today. Can we redefine what we mean by God? Can we apprehend that meaning differently? Can we lay down our theistic definitions of God without dismissing the reality of God altogether? I think we can, and I know we must try. If theism dies, does God die? If Christianity, as a religion, is to survive, it must develop an understanding of the divine which makes sense in the $21^{\text {st }}$ century. That becomes our highest priority.

It was a sixth century BCE Greek philosopher named Xenophanes, who observed that "if horses had gods they would look like horses." 1 The fact that all language is human means that all of the deities that human beings have worshipped throughout history tend to look very much like human beings. Yes, we have removed the human limitations, but the human forms remain. That is why most human ideas of God are expressed negatively. Human life is finite, so God must be infinite, or "not finite," we say. Human beings are bound to a particular place. God must not be so bound, so God is called Omni-present. Human beings are limited in knowledge. God by definition must not be so limited, so God, we say, is omniscient. Human life is mortal. God must transcend this boundary, so we say

${ }^{1}$ See “Horse Gods", Xenophanes (2014). 
that God is immortal. Human beings are limited in power. God must not be so limited, so we say God is omnipotent. On and on we could go, but the result is the same. Every God defined throughout history by any human being is always human-like with all human limits removed. Listen once more to the language of liturgy. "Almighty and eternal God" we pray. What we are saying is: God, you are not limited in power or bound by time. This God is also the all-knowing one who searches the secrets of our hearts. This all-knowing deity becomes little more than a human construct.

If the theistic understanding of God is dead, then the question quickly is raised as to whether it is God who has died or the human definition of God. Can we find a way to talk about God in other concepts with other words? Or is God so identified with our theistic language that God dies when the theistic language dies. That is our modern question.

The Bible has defined idolatry as worshiping something made with human hands. Theism is an understanding of God developed by human minds. Can the ultimate ever be captured inside the limits of human hands or human minds? I do not believe so. Theism is an expression of human idolatry.

So we push aside theism as a definition of our own creation, and we seek to move in a new path into the reality of God. That is a far more revolutionary step than most of us can imagine, but that is the world in which Christianity must learn to live

\section{Thesis n. 2}

"Since God can no longer be conceived in theistic terms, it becomes nonsensical to seek to understand Jesus as 'the incarnation of the theistic deity.' The traditional concepts of Christology of the ages are, therefore, bankrupt." 
Christianity was born in an experience of God associated with the life of a first century Jewish man named Jesus of Nazareth. What the exact dimensions of that experience were is quite difficult to say. The gospels were written $40-70$ years after this man had been put to death, so we do know how those who were his earliest disciples actually articulated that experience in the first generation of Christian history. Most of them had died before the gospels were written. As far as we can gather, the earliest disciples were quite convinced that everything they had ever thought about God had been experienced as present in the life of Jesus. That was the core of the message and that is how Christianity began. At first it appears that the followers of Jesus were content just to exclaim the focus of their experience: "God was in Christ." This is all that the Apostle Paul said early in his Christian life (II Cor. 5:19). He was quite content simply to exclaim his experience; he had no need to explain it. Somehow in Jesus, he believed that he had seen, or engaged the presence of the holy. So writing to the Corinthians, about the year 54, he simply said: "God was in Christ." Later, however, about 56-58 CE, when Paul was writing to the Romans, a community of Christians that he did not found and in which he was unknown, he felt a compelling need to explain what he meant when he asserted that he had met God in the life of Jesus. So in the Epistle to the Romans, Paul suggested that in the resurrection God had lifted the human Jesus into the meaning of God (Rom. 1:1-4). By later standards this was a strange explanation. In time it would be called the heresy of adoptionism, but it was the place to which thinking about the divine nature of Jesus had arrived in the mid to late 50 's.

The problem was one that we have already noted. The human mind can only conceive of God in theistic terms. Theism is a conception of God arrived at by magnifying the qualities of the human. God was an external being, possessing supernatural power. If that was the working definition of God, then the issue became how had this external God got into the life of Jesus, so that the people could have experienced him present there? This was the question that they felt they had to answer, and as those answers developed, they began to shape Christianity in new ways as the years rolled by. 
When the first Gospel, Mark, was written, around the year $72 \mathrm{CE}$, a new explanation of how Jesus and God were connected had entered the minds of the followers of Jesus. In the opening chapter of Mark, the fully human, adult Jesus is brought to the Jordan River to be baptized by one called John the Baptist. In his baptism Mark said that the heavens, the realm of God, opened. The universe was conceived of in those days as a giant astrodome. The sky, the roof separated the realm of God from the realm of the human. The ceiling of the earth was the floor of heaven. So a hole appeared in the roof and the God who lived beyond the sky, simply poured the Holy Spirit from heaven down onto the human Jesus. That is what Jesus' baptism meant as Mark recorded it. It was not a fleeting spirit, but a spirit that was to remain in him forever, a spirit that would ultimately redefine his humanity. In that moment, Mark, said that the voice of God spoke from the sky to proclaim Jesus to be God's son, the son in whom God was well pleased. A study of the scriptures reveals that the words God spoke at this time in Mark were not original. They can be found in the Psalter (Ps. 2:7) and in the book of Isaiah (Is. 42:1). The meaning, however, was that God's presence had been sent to dwell in Jesus, and, true to the disciples' experience, this spirit marked him off as different. He now began to be thought of as a "God-infused human life." That is where the Christian understanding of Jesus was in the $8^{\text {th }}$ decade of the Christian era.

The explanatory process moved on in the $9^{\text {th }}$ and $10^{\text {th }}$ decades when the gospels we call Matthew (ca $85 \mathrm{CE}$ ) and Luke (ca 89-93 CE) were written. In these next two gospels Jesus was thought of, not just as a God-infused human life, but as a God presence that inhabited his human form. The moment in which the theistic God was said to have entered Jesus had been moved from the resurrection, where God adopted Jesus in Paul, to the baptism where God entered Jesus in Mark, to his conception where God was the male agent who gave life to Jesus in both Matthew and Luke. This was the occasion when the virgin birth tradition entered the Christian story. It was a mid to late $9^{\text {th }}$ decade addition to this developing faith story. In Christian thinking the Holy Spirit became thought of as Jesus' biological 
father. His humanity was now permanently compromised. One cannot be fathered by the Holy Spirit and still be fully human!

As substantial as that change was, however, that was not destined to be the final step in Christological development. When the $4^{\text {th }}$ gospel was completed near the end of the $10^{\text {th }}$ decade of the Christian era (ca 95-100 CE), it was said of Jesus that he was a part of God; he was "the Word" of God that was with God from the dawn of creation. The Word of God "became flesh" in the person of Jesus. John was asserting that the theistic God above the sky had in Jesus assumed human form and that in him God was dwelling among us. Jesus was now fully understood to be the incarnation of the God who dwelt above the sky. Both the doctrine of the Incarnation and of the Holy Trinity had been given their biblical basis. The creeds of Nicea and the doctrines and dogmas that followed those creeds now claimed to be able to define God. This proper understanding was later to be enforced by burning those who disagreed at the stake.

If, however, the idea of a God above the sky has become bankrupt, as I believe it has, then the suggestion that this theistic God was incarnated into the human Jesus is equally bankrupt. This means that this primary Christian creedal explanation of Jesus, developed over the centuries, can no longer be applied to Jesus today. Does that mean, however, that the experience, which this explanation sought to explain, is not real or valid? I do not think so, but it does mean that new explanatory words must be sought. The old ones do not work any longer. Every explanation is a human creation. As such, every explanation is both time-bound and time-warped. No explanation, therefore, is eternal. An experience unexplained, however, cannot be passed on, but an explanation that is passed on is never the same as the original experience. Explanations point to timeless truth, they cannot capture it.

What then is that timeless, eternal truth about Jesus, to which our treasured theological words now point so inaccurately? What was there about Jesus that caused people to believe that they had encountered God in him? That is what the 
search for truth in our day compels us to discover. Faith in Jesus as the incarnation of God or as the second person of the Trinity was born in a human experience. What was that experience? It was not the tales of miraculous power that gathered around him. Those details came well after the assertion that "God was in Christ." The conviction about Jesus as the Incarnation of God was not born in the tales of his miraculous power. We can find no evidence that ties Jesus to miracles until the $8^{\text {th }}$ decade of the Christian era. The claim that in Jesus the presence of God has been met antedates the claim of his being a miracle worker by decades. The experience of meeting God in him was also not related to the claim made for him that he had a miraculous or virgin birth. That was an idea added to the Christian story in the $9^{\text {th }}$ decade. It was also not attached to an understanding of the resurrection as the resuscitation of a deceased body back into the life of the world. That was an idea that Luke primarily contributed to Christianity in the $10^{\text {th }}$ decade. The experience of God being encountered in Jesus antedates all of those aspects of the developing Christian tradition. The God experience in Jesus had to have been something original, something transformative. May I submit that it had to do with the qualities of Jesus' humanity, with the wholeness of his life, with the boundary-breaking power of his love and with his ability under every set of circumstances to be his deepest, most authentic self. Perhaps people saw and experienced in his living the "Source of Life," in his loving the "Source of Love" and in his being the "Ground of Being." Perhaps they felt in him and from him the call to live fully, to love wastefully and to be all that each of them could be. Perhaps in those experiences they came to understand that they had confronted the holy in the dimensions of the human. Perhaps the problem with theological explanations was not in the experience they sought to convey, but in the concepts which shaped the words used in the explanations of this new reality. Perhaps the experience is real and, that once the dated and irrelevant explanations are jettisoned, then the reality of the experience can once again be engaged. What was it that caused the followers of Jesus to develop doctrines like the Incarnation and the Holy Trinity and how would we describe it today? 
Can we still think of Jesus today as divine, but not as the incarnation of a supernatural deity who lives above the sky? When the doctrine of the Incarnation was formulated, people thought in dualistic terms. The divine and the human were opposites. Suppose the divine and the human are not two separate realms at all, but one single continuum. Perhaps the way into wholeness and even into divinity is to become deeply and fully human. Perhaps the biological drive for survival is not the ultimate human value, but that ultimate value is to be found rather in transcending the need to survive and being able to give one's self away in love to another. Perhaps when we move beyond our security boundaries of tribe, gender, sexual orientation, race, creed and status, we experience a humanity that is not bound by the drive to survive. Perhaps God is found in the freedom to allow, indeed to accept, responsibility for assisting all others to be what each of us was created to be without imposing our agenda on them. Perhaps that is what Paul was trying to say when he wrote that "God was in Christ," reconciling the world to God and to God's oneness. Incarnation makes no literal sense in a non-dualistic thinking world. It makes infinite sense when it is seen, not an as explanation, but as an experience.

Can we reclaim this Christian concept for the $21^{\text {st }}$ century? I think we can. If Christianity is to survive, I think we must. Christianity might just turn out to be something far more profound that we have yet imagined.

\section{Thesis n. 3}

"The biblical story of the perfect and finished creation from which we human beings have fallen into original sin is pre-Darwinian mythology and postDarwinian nonsense!"

When the familiar biblical story of the six-day creation (Gen. 1:1-2:3) was written, geological records did not exist, so ancient people turned to creation myths to explain their understanding of the world's origins. The Hebrew people experienced the world as good and finished and so they told a story of how God 
created all things out of nothing. Since God was the creator of the world, the world had to be good. The Hebrew myth says that God looked out on all that God had made and pronounced it good. That story also assumed that the work of the creator was complete, for it tells us that when God had finished the creation process on the sixth day, God rested from the divine labor and pronounced the seventh day to be forever a day of rest for all creation. So the biblical narrative, as it is presently constructed, begins with an understanding of creation that suggests that the world was created to be both perfect and complete. This particular narrative of creation was written fairly late in Jewish history, probably during the time of the Babylonian Exile in the late $6^{\text {th }}$ to early $5^{\text {th }}$ century BCE.

Long before this story of creation in six days was written, however, another Jewish myth sought to account for the fact of evil in this world. We know that story as the narrative of Adam and Eve, the snake and the Garden of Eden (Gen. 2:4-3: End). It was written about four hundred years before the six-day creation story was written.

During the Babylonian Exile, under the skillful editorial work of a group of people we call the "Priestly Writers," the four major strands of the Jewish remembered history were woven together. In that edited revision the perfection of creation in six days opened the narrative and it was followed immediately by the story that came to be known as "the fall." Adam, Eve and their forced ejection by God from the Garden of Eden was a part of that fall story. What we need to recognize, however, is that these two stories were not originally connected at all. They were not written to be a continuous narrative.

Following the Council of Nicea in $325 \mathrm{CE}$, and with the official recognition of the legitimacy of Christianity in the Roman Empire, many Christian leaders, but a bishop named Augustine in particular, began to form what became in time the primal Christian myth. They built this myth on the assumption that chapters 1 and 2 of Genesis formed one continuous and infallible story. This primal myth had five 
principles. First, the original goodness and perfection of creation was asserted. Second, the act of human disobedience was offered as that which had plunged God's perfect work into what came to be called the fall and Original Sin. This "fall" distorted God's perfection in everyone and everything. Third, the story of Jesus was told in terms of his being God's rescue operation sent to save the sinful people and a sinful world from its fall. Jesus accomplished his purpose, the ancient myth suggested, by "paying the price," which God required and by absorbing the punishment, which the sinfulness of human beings deserved. This act of redemption was accomplished by what came to be called the "sacrifice of the cross." From this $4^{\text {th }}$ century CE theological perspective came the words: "Jesus died for my sins," which achieved in a relatively short time the status of a historic Christian "mantra." This understanding of both God and Jesus came to be reflected in our hymns, our prayers, our liturgies and our sermons. "Jesus overcame the separation that sin had created," was the message. The greatness of God, this mantra asserted, was seen in that "God stooped to save one as evil and as worthless as me." God's grace was called "amazing" because it "saved a wretch like me." "The Old Rugged Cross" was the place where Jesus for a "world of lost sinners" shed his blood. As this theological understanding became dominant in Christian history, the sinfulness of human life was emphasized continuously in Christian liturgies. We Christians were trained to approach God on our knees as slaves might do before the master. We were taught to pray constantly for mercy, to call ourselves "miserable offenders," people in whom there was "no health," or wholeness and as people who were "not worthy to gather up the crumbs" under the divine table. Our sinfulness was presented as both the cause and the reason for Jesus' suffering. Guilt thus became the coin of the Christian realm. Salvation came through acknowledging that the suffering and death of Jesus for us had been achieved since God, in the person of Jesus, had absorbed the punishment, which human beings deserved.

Baptism was created to be the sacramental way of washing "original sin" from off the new born baby. Unbaptized children, who died in the "sin of Adam," were said to be condemned to an eternity apart from God. The Christian Eucharist was the meal, which provided the first taste of the Kingdom of God. Faith in the 
resurrection meant that Jesus had conquered death by ending the punishment that God required for the sin of Adam, which had distorted God's perfect world. So in the cross Jesus, by dying, paid our debts, absorbed the punishment that we deserved and thus won for us our eternal salvation. That is why in the developing Christian tradition the primary titles by which Jesus was called became "savior," "redeemer," "rescuer." Finally, we were taught that in Jesus' sacrificed life, human beings were restored to their original perfection and that eternal life was the culmination of our newly won restoration.

This theological framework became so powerful in Christian theology that it swept over all other possibilities. It claimed every aspect of the Christian proclamation. It made "Incarnation" necessary. It undergirded the doctrine of the Holy Trinity. It was the definition behind the doctrine of the atonement. It produced the fetish in Christian history that focused on the "saving blood" of Jesus. It shaped the entire Christian liturgy.

It also did some rather terrible things that did not get noticed for centuries. It turned God into a monster, who did not know how to forgive. It portrayed a God who demanded a human sacrifice and a blood offering before it was possible for God to extend forgiveness. It told the story of God the father, who punished with death God the son in order to satisfy the divine need for retribution. Unknowingly, this concept turned God the father into the ultimate "child abuser!"

Secondly, this theology turned Jesus into a chronic victim who was never allowed to escape his cross, since the ongoing sins of human beings required his continuing suffering and his death. As the primary Christian icon we offered the picture of Jesus eternally dying on the cross.

Thirdly, this theology filled you and me with an overwhelming, even a debilitating sense of guilt. We were turned into being the "Christ killers." As one of 
our hymns proclaimed: "T'was I Lord Jesus, I, it was, denied thee. I crucified thee."2 Can any of us imagine a greater guilt message?

An analysis of these themes, which came to constitute what we called "Atonement Theology," will convince us quickly that this is a destructive and lifedenying way to view both Jesus and the Christian story. This theology assumes a discredited and dated anthropology that, when once exposed, renders it immediately both null and void. Atonement theology assumes a theory about the origins of life that no one in the astrophysical or biological world today still holds to be valid. The premise on which atonement theology is based is demonstrably a false one. Since the work of Charles Darwin in the middle of the $19^{\text {th }}$ century, we have known that there never has been an original perfection (DARWIN ,1859). Human life was rather the product of a biological journey from a single cell of life that came into being some 3.8 billion years ago. From that original single cell, life has gone through many stages from single cells to cell clusters, from cell clusters into complexity and from complexity into a division between animate life and inanimate life, just to name a few. All of this was over hundreds of millions of years. About six hundred million years ago, life in both its plant and animal forms, abandoned the sea and began to take up residency in the river beds and estuaries, where it waited until this planet finally became hospitable to life. Then these life forms moved out of the water and onto the dry land, where they adapted to their new environment and began to interact, producing a multiplicity of new forms. From about one hundred and eighty million years ago to about sixty five million years ago the reptiles ruled this planet. The dominant reptiles were the dinosaurs, and thus they occupied the top of the food chain. On planet earth the dinosaur had no equal and thus no natural enemies. Some natural disaster, however, struck the earth about sixty five million years ago and that disaster dramatically changed the climate, scrambling, in the process, all of the forms of life. This natural disaster is thought by most scientists to have been the result of a collision of a giant meteor with the planet Earth. Whatever it was, it produced a change in climate that

\footnotetext{
${ }^{2}$ The Lenten hymn "Ah, Holy Jesus."
} 
ultimately rendered the dinosaurs extinct and opened the gates for the mammals to begin their rise into prominence. From these warm-blooded, inside-egg-producing, mammals there finally emerged from the line of the primates, a human-like creature. This happened some four to five million years ago. Over those years, the brain of these human-like creatures expanded, the jaws receded, the larynx dropped, speech developed and ultimately this creature passed the great divide, going from being merely conscious to being self-conscious. This creature was now aware of its own "separate-from-nature existence. It also embraced its own mortality. It began to plan for its own death and it developed a kind of chronic existential anxiety that no animal had ever known before. The anxieties of selfconsciousness were so severe; this creature had to develop coping devices. Religion was one of those coping devices. The object and focus of religious thinking was a human-like deity, who possessed supernatural capabilities. This deity could do all the things that self-conscious creatures could not do, including escaping mortality. God was originally conceived of, we have already established, after the analogy of a human-being, but with all human limitations removed. This anthropomorphic God was in charge of the universe and so to this supernatural power anxious human beings could appeal for help. These are, in the briefest of details, the story of the origins of life on planet earth.

As this human creature gained more knowledge of the origins of the universe, however, it became clear that there never was an original perfection and that creation was itself an ongoing, never finished process. This also meant that all the forms of life on earth were never set, and thus were always changing. There is nothing static about life. There never has been anything static about life and there never will be. Note, also, that there never was an original act of creation, but rather an on-going, ever-evolving process. Now look at what these insights mean for our understanding of Christianity.

If there was no original perfection there could never have been a fall from perfection into sinfulness. That means that the idea of "original sin" is simply 
wrong. If the idea of "original sin" is not an accurate description of human origins, then it has to go. Other things also begin to fall and be dismissed. If there was no original sin, there was also no need for anyone to be saved from this sin or rescued from this fall. One cannot be rescued from a fall that never happened. One cannot be "restored" to a status one has never possessed. Suddenly the whole framework, which for centuries had formed the basis of the Christian story, collapsed. It is not an accurate reflection of our origins at all. This particular story of salvation thus ceases immediately to be capable of translation into anything that has any chance to be credible in our $21^{\text {st }}$ century minds. It is, therefore, not capable of being grasped by the devotion of our hearts, since the heart will never be drawn in worship to that which the mind rejects as real.

We can, therefore, no longer pretend that in these concepts we can continue to tell the Christ story in our contemporary world. It simply does not work. The question for many then becomes can we continue to tell the Christ story at all? Can we separate the reality of the Christ from the interpretive framework of the ages, in which that reality has been captured, and still find in him something, that speaks to and enhances our humanity? Can we break the barriers that separate us from one another and then find a sense of oneness in him? Can we, through this Jesus figure, dip into the wellsprings of life, open ourselves to a transforming love and through him find the courage to be all that we can be?

The old words will never carry us to these goals. Despite that, there will always be some who are unwilling to leave their ports of security, those who will act as if the old words must be clung to forever. They will do this primarily because no one has ever suggested to them that there is another way to tell the Christ story. They fear that the story itself will die if the old words, which carried this story for so long, have to be abandoned. The Church of tomorrow, however, cannot be impeded by those who cannot embrace the new reality. The quest for new words in which to tell our story must become the major agenda of the Christian Church in our time. If we do not embrace these changes there will be no hope for a Christian future. Please understand that death may still come when we abandon these words 
of antiquity. We cannot be sure that we modern Christians can make the necessary transition. What we know as a fact, however, is that death will certainly come if we do not abandon yesterday's formulas. We live at a critical juncture in Christian history. Our time requires heroic leadership that will probably be mostly resented by those who call themselves "the faithful." Is saving Christianity worth the effort and worth the cost? I think it is. The call for radical reformation is the call our generation must answer. It will start with a new understanding of what it means to be human. We are not fallen sinners, we are incomplete human beings. We do not need to be saved from our sins, we need to be empowered to embrace life in a new way.

\section{Thesis n. 4}

"The virgin birth understood as literal biology makes Christ's divinity, as traditionally understood, impossible."

When the virgin birth entered the Christian tradition in the $9^{\text {th }}$ decade of the Christian era in the gospel of Matthew, people's understanding of the reproductive process was rather primitive. No one had ever heard of the possibility that the woman had an egg cell and was, therefore, genetically, a co-creator, equal in every way with the man, in the birth and development of every human life that had ever been born. People in that era rather thought that the new life lived in the spermatozoon of the male and that he simply planted this life in the female in the same way that a farmer plants his seed into the soil of Mother Earth. The woman, like Mother Earth, served only as a receptacle, or the incubator, for the growth of the baby or the seed; she did not add to it. This meant that whenever the claim was made in the ancient world for an extraordinary life, which could not be accounted for without the suggestion of divine origins, there was, in the development of the explanation of the myth, a need to replace only the male with the divine source. Since the female was thought to contribute nothing to the new life, she could easily become the receptacle for a divine child, as well as a human child. Given that 
understanding of the reproductive process, miraculous birth stories and virgin birth stories were frequently told about extraordinary lives. It was, therefore, not surprising, that in the ancient world in time one such miraculous birth story was devised for Jesus to explain the source of his extraordinary power. That kind of story, while not original in Christianity, did manage to enter the tradition about 55 years after Jesus' crucifixion. It is of interest to note that Paul, who wrote between the years 51-64 or 21-34 years after the crucifixion, never seems to have heard of the tradition of Jesus having had a miraculous or a virgin birth. Indeed, Paul appears to have assumed a very ordinary birth for Jesus. In his second epistle, Galatians, written about the year 52, Paul speaks of Jesus' origins, describing him in totally unremarkable ways as having been "born of a woman," like every other human being, and having been "born under the law," like every other Jew (Gal. 4:4). Paul in this same epistle also asserted that James was "the brother of the Lord," by which he clearly meant Jesus' blood brother (Gal. 1:19). James, indeed, has achieved his position of influence in the Christian movement, based totally on that fact of his physical relationship of Jesus. In Romans, written between 56-58, Paul adds another claim regarding Jesus' origins and again it has no connection to a miraculous birth. Jesus was, Paul wrote, "descended from the House of David according to the flesh," and "designated son of God by the resurrection" (Rom. 1:14). There was nothing about Jesus' birth that was unusual in the entire Pauline corpus. He never mentions the virgin birth, because it had not yet been developed.

When Mark wrote the first gospel, about the year 72, or 42 years after the crucifixion, there was still no miraculous birth story in the tradition. That kind of narrative still had not been born. In Mark the Holy Spirit entered Jesus not at conception, but at his baptism in the river Jordan (Mark 1:9-10). Presumably before his baptism he was not God-infused. To underline the normalcy of Jesus' birth Mark also asserts (Mark 3:21ff) in a story about the mother of Jesus, along with his brothers, that they had come to believe that Jesus was "beside himself," that is mentally disturbed. In that passage (Mark 6) the brothers are named as James, Joses, Simon and Judas. Concerned, these members of his family come to "take him away" (Mark 3:31ff). That is hardly appropriate behavior from one to 
whom an angel might have announced that she was to be the bearer of the messiah. One does not entertain an angelic annunciation prior to pregnancy only to conclude, when the child is full grown, that he has become an unbalanced adult! Mark clearly was not aware of the tradition or a supernatural birth for Jesus. He had not heard of it because it had not yet been created.

That virgin birth tradition enters the Christian story first in Matthew about the middle of the ninth decade, around the year 85 of the Christian era or some 55 years after the crucifixion and 85-90 years after Jesus' birth (Matt 1:18-25). The virgin birth story is then repeated by Luke about a decade later, but in a very different and even an incompatible way (Luke 1:26-80). Then, much to the surprise of many, the story of Jesus' miraculous birth disappears completely in John's gospel, finished near the end of the tenth decade or 65-70 years after the resurrection. John not only omits the miraculous birth tradition altogether, about which he almost certainly would have known, but he goes on to speak of Jesus on two occasions simply as "the son of Joseph," once in chapter 1(1:35) and once in chapter 6 (6:42). The virgin birth story is not history, it is not biology, it is mythology designed to interpret the power of a life. It is the power that is real, not the reproductive process.

Now we go back to what we know today about human reproduction. When the sperm of the male fertilizes the egg from the female, the offspring is the blend of the two genetic sources. If we, in the light of today's knowledge, literalize the virgin birth story, treating it as biology instead of mythology, then Jesus cannot possibly be either fully human or fully divine! Yet that was the substance of what the great councils of the Church sought to proclaim: a literal virgin birth, understood biologically, with the Holy Spirit providing the male seed and the Virgin Mary the female egg; that process would produce not one fully human and fully divine, but rather a life half divine and half human. That is not Incarnation!

The ramifications of this new understanding are far greater than most 
imagine. First, one cannot be fully human if the Holy Spirit is one's father. That seems elementary! Secondly, the mother of Jesus as co-creator would inevitably pass on to Jesus the effects of "the fall" since she, was also a child of Adam. So the idea of Jesus having been "born sinless" disappears. Science discovered the egg cell in the woman in the early years of the $18^{\text {th }}$ century. Perhaps that is why the Church was forced more than a century later to come up with a new doctrine entitled the "Immaculate Conception of the Virgin." 3 Her birth had to be lifted out of human biology so that she could bear the Christ Child without passing on to this "sinless one" the corruption of the fall. So Mary's birth was the place where sin, "original sin," was stopped. Her conception was, therefore, said to be sin free or "immaculate."

If one literalizes the virgin birth with today`s understanding of reproduction the result would be that Jesus could be thought of after the analogy of a mermaid, a creature half human and half something else, or like one of the figures in Greek mythology that has an animal's body with a human head. A literal virgin birth quite literally would destroy the essential claims articulated both in the doctrines of the Incarnation and the Holy Trinity.

What then does the story of the miraculous birth of Jesus mean? Why was it developed and applied to Jesus? The answer to that is clear. That was the only way that first century disciples could proclaim that they had met in Jesus the presence of God. This was the way that the followers could validate the claims of their experience, namely that human life could not have produced what they believed was the God presence they had encountered in Jesus of Nazareth.

We Christians worship the God revealed in and through the humanity of Jesus. The myth of the virgin birth will never give us that. It is, therefore, not meant to be literalized. It is not about biology. We Christians need to stop pretending that it was ever anything more.

\footnotetext{
${ }^{33}$ Adopted as Dogma by the Roman Catholic Church in 1854.
} 


\section{Thesis n. 5}

"The miracle stories of the New Testament can no longer be interpreted in our post-Newtonian world as supernatural events performed by an incarnate deity."

Miracles are not unique to Jesus in the Bible. Moses performed miracles in the Hebrew Scriptures, some of which were rather bizarre. In one Exodus story, Moses cast his staff to the ground and it became a snake (Exod. 7:8-13). Some of them were manipulative of divine power like the plagues of Egypt (Exod. 7:12). Joshua also performed miracles in the Hebrew Scriptures by parting the flooded waters of the Jordan River (Josh. 3:1-10) and by stopping the sun in its journey around the earth to allow more daylight for his army to rout his enemies, the Ammonites, (Josh. 10:12ff).

Later in the biblical story, both Elijah and Elisha performed miracles. They were both able to control the weather and to expand the food supply (I Kings 17, II Kings 4, 7). Healing miracles also make their appearance in the Elijah-Elisha cycle of stories (II Kings 5), as well as raising-of-the dead stories (I Kings 17, II Kings 4:18ff).

The third place in the Hebrew Scriptures where miracles are mentioned is in Isaiah. Miracles were said by the prophet to be among the signs that would accompany the dawn of the Kingdom of God on Earth. On that day, said the prophet: "The eyes of the blind will be opened; the ears of the deaf unstopped; then shall the lame man leap like a hart, and the tongue of the dumb sing for joy" (Isaiah $35: 5-6)$.

I believe we can now show that almost all of the miracles attributed to Jesus can be explained as either expanded versions of Moses stories, Elijah stories or Elisha stories, plus the messianic application to the life of Jesus Isaiah's signs of the coming Kingdom of God. If Jesus was the messiah he would inaugurate that 
kingdom and then the signs of the kingdom would be apparent in his life. The miracles would then be interpretive signs, not supernatural events that violated the laws of nature.

It is of interest to note that Paul seems to have had no awareness at all those miracles were ever associated with the memory of Jesus. For those who want to argue that the Q Document and even the gospel of Thomas were earlier than Mark (I am not among them), I find it noteworthy that neither of these documents portrays Jesus as doing miracles.

Miracles associated with Jesus are first introduced into the Christian tradition by Mark early in the $8^{\text {th }}$ decade of the Christian era. Then these miracles are repeated almost verbatim by Matthew, written in the middle of the $9^{\text {th }}$ decade. Then they are both repeated and expanded by Luke in the late $9^{\text {th }}$ and early $10^{\text {th }}$ decades. Next they are turned into signs in the latter years of the $10^{\text {th }}$ decade in the gospel of John. A sign is not just an event that can be described, a sign points beyond itself to something it cannot possibly contain. The Fourth Gospel records seven signs attributed to Jesus (John 2 to 11). It is noteworthy, I believe, that the first of John's signs, the turning of water into wine at a wedding feast in Cana of Galilee (John 2) and the last of his signs, the raising of the four-days dead Lazarus from the grave (John), had never been mentioned or even alluded to in any Christian writing before John, who wrote 65-70 years after the crucifixion.

The texts of the miracle stories in the gospels that purport to tell us of Jesus' supernatural power are filled with interpretive symbols. The loaves that were expanded to feed the multitude in Mark, were five in number on the Jewish side of the lake where 5000 men (plus women and children) were fed and twelve baskets of fragments were gathered after all had eaten (Mark 6:30-44). Then on the Gentile side of the lake the loaves were seven in number and four thousand were fed and afterwards seven baskets of fragments were gathered of the leftovers (Mark 8:1-10). That seems to me to be a list of interpretive clues offered by the authors of the gospels, as they turn the story of Moses providing manna in the wilderness to 
feed the Israelites into a narrative about Jesus. Remember that Jesus will ultimately be called "the bread of life," the one who satisfies the deepest hunger in the human soul (John 6). If we could only open our eyes to see that the miracle stories of the New Testament are not to be read as literal, supernatural events, we would come a lot closer to what the original gospel writers had in mind as they sought to enable the Isaiah 35 text to be fulfilled in the gospels.

I could expand this exposition of the miracles almost endlessly: Jesus raising from the dead a child (Mark 5:22) is reminiscent of the account of Elisha raising from the dead a child (II Kings 4:32-37). Jesus' raising from the dead of a widow's only son in the village of Nain (Luke 7) is reminiscent of Elijah raising from the dead the only son of a widow (I Kings 17). Jesus' response to the question of the messenger from John the Baptist while he was in prison brings the Isaiah 35 text into the gospel tradition (Matt. 11:1-6 and Luke 7:18-23).

\section{Thesis n. 6}

"The view of the cross as the sacrifice for the sins of the world is a barbaric idea, based on primitive concepts of God that must be dismissed."

In the book of exodus the story is told that the anxiety of the people rose to dangerous levels after Moses had been away too long from them, while supposedly receiving the Torah and the Ten Commandments from God. In order to allay their anxiety, they went to the high priest, Aaron, Moses' brother, and asked him to make for them an idol, a golden calf; so they could have a deity they could see. Aaron did so, and when the golden calf was complete, the people danced around this idol and said: "This is the God who brought us out of Egypt" (Exod. 32:1-6).

Moses returned to the people at just that moment, bearing, the biblical story tells us, two tablets of stone on which the Ten Commandments had presumably been written. On seeing this lapse into idolatry, Moses smashed the two tablets of 
stone on the ground and confronted the people, who, according to the story, then endured the wrath of Moses and the wrath of God, until finally Moses said he would return to God and try to work out "atonement" for the people (Exod. 32:30). In that early reference we note that atonement was about forgiveness. It was about God being the God of second chances.

When Yom Kippur, the Day of Atonement, was placed into the Jewish worship life, according to the book of Leviticus that was its purpose, to celebrate God's forgiveness, not God's punishment (Lev. 23:26ff). The Jews called Yom Kippur "the Day of Atonement," not "The Day of the Atonement" because forgiveness was not a one-time event, but an on-going process.

Yom Kippur involved the sacrifice of animals that represented the human dreams of perfection. These animals had to be physically perfect. They were scrupulously examined to certify that on these animals' bodies, there were no scratches, no bruises and they had never had any broken bones. With physical perfection established, they began to claim a moral perfection for these creatures also. The reasoning was complex, but logical. Animals live beneath the level of decision-making ability. They cannot choose to do evil, so a moral perfection could also be claimed for them. These animals could, therefore, represent, symbolically, the perfection for which all human beings yearn. So it was that on the Jewish Day of Atonement, human beings could come into the presence of God, despite their sinfulness, because they came under the symbol of a physically, morally perfect creature.

When Gentiles got hold of this idea they thought of the animals as required sacrifices that had to be slain as an offering to God before God could forgive. These animals were the price God required to be paid to God in order for God to forgive.

In the liturgy of Yom Kippur in the first century the two animals tended to be a lamb and a goat. The lamb was slaughtered, its blood drained and the high priest, after undergoing an elaborate, ceremonial cleansing, would go into the Holy of Holies, the inner sanctum of the Temple, where the earthly throne of God, called 
"the Mercy Seat," was located. He would then smear the blood of the perfect Lamb of God on that place until it covered the Mercy Seat. This meant that the people, no matter how far short they had fallen of what God intended, could still come into God's presence, for they came "through the blood of the perfect lamb." Yom Kippur was about reconciliation, about human life being made at one with God. It was not about punishment.

When the ritual of the lamb was complete, the second animal, the goat, was taken to the high priest in the assembly of the people. The high priest, grasping the horns of the goat, would then begin to offer prayers of confession in the name of the people. The symbol operating here was that all of the sins of all of the people would be lifted out of the people and be able to land on the head and back of the goat. Then the goat, as the sin bearer, laden with the sins of the people was subjected to the loud curses of the people, who called for the goat's death. The goat was not slain, however, instead an opening was created in the assembly of the people and the goat was driven out into the wilderness, bearing the sins of the people with it. Thus, the people were left cleansed and sin free, at least for a day. Yom Kippur was about the people being restored to God. It was not about punishing the people.

When the gospels were being composed the images of Yom Kippur were drawn into the story of Jesus time after time.

Paul began the process in I Corinthians when he told the story of the crucifixion. "He died for our sins in accordance with the scriptures," he wrote (I Cor. 15:3). It was a clear reference to the liturgical action of Yom Kippur. Later Mark used the word "ransom" to refer to the death of Jesus (Mark 10:45). Once again it was a concept drawn from the liturgy of Yom Kippur. When the Fourth Gospel was being written near the end of the first century this author put into the mouth of John the Baptist, the first time he saw Jesus, these interpretative words: "Behold the Lamb of God who takes away the sins of the world" (John 1:29). These words come right out of the liturgy of Yom Kippur. 
There were other places where the liturgy of Yom Kippur seems to have shaped the story of Jesus. When Pilate presents Jesus to the crowd, the response of the people was to utter curses and to call for his death. "Crucify him, crucify him," the people were supposed to have said. Jewish readers would have recognized this bit of pageantry as coming directly out of the liturgy of Yom Kippur. The sin bearer deserved to be crucified (Mark 15:13, Matt. 27:22).

When the story of Barabbas was introduced into the crucifixion narrative, we may have another reference to Yom Kippur (Mark 15:6ff). Barabbas is a name made up of the Hebrew or Aramaic words "bar," which means son, and "Abba," which means God or father. So Barabbas means literally "son of God." So in the gospels at the time of the crucifixion, there were two sons of God, just like Yom Kippur there were two animals. In the gospels, one son of God, Jesus, was sacrificed and one son of God, Barabbas, was set free. In the liturgy of Yom Kippur, one animal, the lamb, was sacrificed and the second animal, the goat, was set free. Could that also be a place where the symbols of Yom Kippur shaped the story of the crucifixion? I believe it was.

Later generations of Gentile Christians, who were unaware of the Jewish tradition of Yom Kippur, then turned these symbols into a crude literalization and developed the ideas that are now associated with what is called "substitutionary atonement."

This concept begins with a sense of the depravity of human life, which was said to have fallen into "original sin" because of human disobedience of God's divine rules. "You are not to eat of the tree that is in the midst of the garden," Adam and Eve were told. The fruit of the tree, the tree of the knowledge of good and evil, was to be avoided on pain of death (Gen. 3:1-7). When this rule was broken, so, it was assumed, was God's original perfect and finished creation. The disobedient human beings were then banished from the presence of God in the Garden of Eden and forced to live "East of Eden." 4 They were so corrupted by

\footnotetext{
${ }^{4}$ The title of a John Steinbeck novel (STEINBECK, 2004).
} 
original sin that only God could restore them in an act of divine intervention. Since the punishment for their sin was greater than any human being could endure, the idea developed that God would be forced to punish the divine son in place of the deserving sinner. So a substitute was arranged and Jesus became the victim of the divine wrath. God punished Jesus instead of the deserving sinner. "Jesus suffered for me," the Christians began to say. "Jesus died for my sins" became the mantra of the Christian life, but at a very terrible price.

Atonement theology thus proceeded to shape Christianity dramatically. To repeat from the exposition of one of the earlier theses, God was turned into a monster who could never forgive. This punishing deity demanded a victim, a human sacrifice, a blood offering before forgiveness could be made available. This was no longer a God of a second chance.

Jesus was turned into the chronic victim of this punishing God. The Divine Son absorbed the punishment of the Divine Father.

This theology in turn created a world, not of disciples, but of victims. We became those responsible for the death of Jesus. We became the guilt-filled Christkillers.

The ramifications of this theology, as we have noted earlier, are everywhere in the Christian tradition. In time this theology meant that our primary response in worship was to offer pleas to God for God to have mercy. "Lord, have mercy, Christ have mercy, Lord have mercy." We still have in our liturgies three-fold kyries and nine-fold kyries. Kyrie eleison is simply Greek for "Lord, have mercy."

What kind of God is it before whom we are reduced to being slavish petitioners begging for mercy? A quivering child standing before an abusive parent might appropriately beg for mercy. A convicted felon, standing before a hanging judge might appropriately beg for mercy. Would this attitude, however, ever be considered to be the proper behavior of a child of God standing before the one who 
is conceived of as "the Source of Life," "the Source of Love," and "the Ground of Being?" I do not think so.

Substitutionary atonement is wrong in every detail. Our problem is not that we are sinners, who have fallen from an original perfection into something called original sin; our problem is that we are incomplete human beings yearning to be expanded and made whole. We do not need to be saved from a fall that never happened. We need to be accepted just as we are, and loved into becoming all that we can become. We also cannot be "restored" to a perfection we have never possessed!

Christianity based on the idea of a substitutionary atonement is a Christianity based on an inaccurate and inappropriate vision of what it means to be human. Good theology can never be built on bad anthropology. We are not fallen sinners, who need to be saved. We are incomplete human beings, who need to be made whole.

That difference is crucial, and the Christianity that recognizes that difference will be the Christianity that will survive and endure into the future.

\section{Thesis n. 7}

"Resurrection is an action of God. Jesus was raised into the meaning of God. Resurrection, therefore, cannot be a physical resuscitation occurring inside human history."

Nothing frightens traditional Christians more than trying to understand the Easter Moment as something other than a deceased man returning from the dead to reenter the life of time and space in the world. Nothing, however, in the New Testament itself supports that literalistic and fanciful understanding of what the resurrection actually was and what it still is. 
It is interesting to note that Paul, the first writer of any book in the New Testament, never describes the appearance of the raised Christ to anyone. $\mathrm{He}$ simply gives us a list of those who were witnesses to the resurrection (I Cor. 15:1-6 written about $54 \mathrm{CE}$ ). In that list he includes himself, different, he says, only in that the appearance to him was last. Scholars estimate the time of Paul's conversion to be no earlier than one and no later than six years after the crucifixion (HARNACK, 2004). Was it a resuscitated physical body that Paul saw? Was a resuscitated body still around that much later? Luke certainly did not think so. Luke portrays Paul's conversion, his seeing of the raised Jesus, as coming as a result of a vision on the road to Damascus, not as a physical body (Acts 9:11ff). Luke also has the physical body leave the earth in an act of Ascension forty days after Easter (Luke 24 and Acts 1).

When Mark, the first gospel, tells the story of the resurrection, he never records a narrative of the raised Christ appearing to anyone (Mark 16:1-8)5. Rather, there is a messenger who announces that Jesus has been raised and will go before them back to Galilee. They will see him when they return to their homes.

The Easter stories in the New Testament, when looked at together, are proof of nothing. They disagree on every salient point regarding the Easter moment. They disagree on who went to the tomb; every gospel has a different list of women. They disagree on whether the women saw the risen Christ. They disagree on whether the disciples first saw the raised Christ in Galilee or in Jerusalem. They disagree on who was the first to see him. They disagree on whether the ascension came before the appearances of the raised Christ or after them.

That kind of comparison could mean that there was no objective moment of resurrection and so all we have are subjective theories. It could, however, also mean that what we call "resurrection" was so powerful and transforming an experience that words could not contain it and that what we are seeing in the

\footnotetext{
${ }^{5}$ Verses 9-21 of Chapter 16 are a later addition to Mark. See RSV Bible (2014).
} 
contradictions is nothing more than subjective attempts to give expression to what was and will always be an experience of wordless wonder.

I believe the resurrection of Jesus was real. I do not believe it has anything to with an empty tomb or a resuscitated body. It is a vision of one not bound by any of the limitations of our humanity. It is a call into a new level of consciousness, a call into a new reality beyond time and space.

I cannot in this brief paper go into the details of Easter as thoroughly as I did in my 300 page book entitled Resurrection: Myth or Reality: A Bishop Rethinks the meaning of Easter, which is available in Spanish. Space here simply does not allow for that kind of thoroughness. So let me simply conclude this resurrection thesis by stating my ultimate conviction: Easter is profoundly true, but it is not capable of being literally described.

\section{Thesis $\mathbf{n} .8$}

"The story of the ascension of Jesus assumes a three-tiered universe and is, therefore, not capable of being translated into the concepts of a post-Copernican space age."

When the story of Jesus was written in the gospels between the years 70-100 of the Common Era, as we noted earlier, there was a consensus that the earth was the center of a three-tiered universe. Heaven the dwelling place of God was in the tier above the sky; hell, the dwelling place of the devil was beneath the earth forming the third tier. No one embraced the vastness of space. No one understood how fast light traveled. No one was aware of other universes or even of other galaxies. No one knew that space was still expanding, that galaxies were still being formed. So much of the traditional understanding of Christianity assumed presuppositions based on pre-modern knowledge.

Therefore, it was not difficult for people to understand that when Luke introduced into the Christian tradition, probably in the $10^{\text {th }}$ decade of the common 
era, the story of Jesus' return to God, he did so in the spatial images of a threetiered universe. Jesus could return to the God who lived above the sky only by rising into the sky. It all made perfect sense in that pre-modern world. Our knowledge of the world and of space has, however, changed dramatically in the centuries since that time.

We now know that our sun is one of about two hundred billion stars in our galaxy that we have named the Milky Way. Our sun is not even in the center of our galaxy, it is located about two-thirds of the way out from the center of that galaxy. Our sun is not very large, relatively speaking. Other stars in our galaxy dwarf the sun. One of the stars in our galaxy is larger not just than the sun, but larger than the earth's orbit around the sun.

Next we came to understand that our galaxy is not the only galaxy in the universe. Andromeda, our closest galactical neighbor, is millions of light years away. There are in the visible universe somewhere between one hundred billion and one trillion galaxies and our universe is still expanding.

Is it in that kind of world that we now have to ask what does the story of Jesus' ascension mean? Does it make any literal sense? Of course not. This was pointed out to me so provocatively when Carl Sagan, one of our greatest astrophysicists, said: "If Jesus literally ascended into the sky and if he traveled at the speed of light, approximately 180,000 miles per second, he has not yet escaped the boundaries of our galaxy."6 It takes light more than 100,000 years just to go from one end of our galaxy to the other. The ascension of Jesus, if literally understood, was only about 2000 years ago.

A study of the scriptures will reveal, however, that Luke knew he was telling a story based on the narrative of Elijah's ascension told in II Kings 1. Luke never intended his writing to be understood literally. We have greatly misrepresented

\footnotetext{
${ }^{6}$ In a personal conversation in Washington, D.C. in 1994.
} 
Luke's genius by reading it literally. Luke was talking about how the God met in in Jesus was not different from the ultimate God who inhabits eternity. A story designed to convey a truth is not astrophysics. Finally we are learning that the time has come for Christians to say so openly and honestly.

\section{Thesis n. 9}

"There is no eternal, revealed standard written in scripture or on tablets of stone that will govern our ethical behavior for all time."

Did God write the Ten Commandments? Of course not. There are three different versions of the Ten Commandments in the Bible. One is in Exodus 34, which appears to be the oldest version. The second is in Exodus 20. That is the familiar version that frequently hangs in churches and sometimes even in court rooms. This version, we now know, has been significantly edited by a group of people we call "the $\mathrm{P}$ writers or Priestly writers," who substantially expanded the Torah, while the Jews were exiles in Babylon. The final version of the Ten Commandments is in Deuteronomy 5 and reflects a time in Jewish history before the first chapter of Genesis, with its seven day creation story, was written. The reason one should refrain from labor on the Sabbath in this version was not that God rested from the divine labors of creation and mandated the Sabbath for all time as a day of rest, but that the Hebrew people were not to forget that once they were slaves and even slaves need a day of rest. No, God is not the author of the Ten Commandments.

Another interesting fact of biblical history is that the Ten Commandments were not universal laws at the beginning. They were laws designed only to govern the relationships between Jews and Jews. The commandments say - you shall not kill. Yet God was reported in the Book of Samuel as instructing the prophet to tell Saul to go to war against the Amalekites and to kill every man, woman, child, suckling, ox and ass among the Amalekites (I Sam. 15:1-4). That sounds like genocide to me. So much for "Thou shalt not kill." The Commandments say you 
shall not bear false witness. Yet the book of Exodus portrays Moses as lying through his teeth to the Pharaoh about why he should let the Israelites go out into the wilderness to offer sacrifices to God (Exod. 5:1-3). The moral code of the Bible was always adjusted to the needs of the people. That is just the way it is. The claim of divine authorship of the moral code was simply a tactic employed to gain compliance.

For every rule there is always an exception. Every class that is taught on ethics is aware of that. Is stealing wrong? Of course, we answer quickly out of our religious training, stealing is wrong. Suppose, however, the oppression of the poor by the economic order is so extreme that stealing a loaf of bread is the only way to keep your child from dying of starvation. That was the theme explored in Victor Hugo's novel, Les Miserable. The thief, Jean Valjean, was the hero of the novel, while the righteous and relentless pursuer of Valjean, Inspector Javert, was the evil one (HUGO, 1862). Is adultery wrong? Yes, we answer out of our moralistic training, adultery is wrong. Suppose, however, that war separates families and they do not know whether husbands and wives are alive or if they will ever see each other again, is a life-sustaining sexual liaison sinful in those circumstances. That is the theme that Boris Pasternak pursues in his novel (PASTERNAK, 1957). Is war wrong? Yes, we answer, war is wrong. Suppose, however, war is the only means that will stop slavery or the only means that will stop the Holocaust. Then is war wrong?

We could go on and on until we realize that there is no ethical absolute that cannot be tempered by the relativities of ongoing life. The ultimate ethical standard cannot therefore ever by found simply by following the rules.

How then do we learn to act in the light of the exigencies of ordinary life? It is not the rules that guide us so much as it is the goals we seek. If the ultimate form of goodness is expressed in the discovery of the fullness of life, then every moral decision, even those where right and wrong are not clear, needs to be addressed, 
not according to the moral laws, so much as according to the desired end. The question that must be raised by every action is this: Is humanity expanded or affirmed, heightened or repressed by this deed? Does this action minimize or enhance life, increase or diminish love, call one into a deeper sense of being or repress one's being?

If God is a verb to be lived rather than a noun to be defined, as I have previously suggested, then moral codes are tools to be appreciated, not rules to be followed. What is the result of this idea? It is that no set of rules can force one to be ethical. It is that living the ethical life means that every decision must be weighed in the light of everything that we know. It is not always easy to make the right decision. It is not easy to be a Christian in the $21^{\text {st }}$ century.

\section{Thesis n. 10}

"Prayer cannot be a request made to a theistic deity to act in human history in a particular way."

Of all the subjects about which I have written, questions about prayer and its efficacy always elicit the largest response. I think that is because prayer is the activity through which people ultimately define who God is for them and what they mean when they say the word "God."

Behind the anxiety that people have when prayer is the subject of discussion is always their definition of God. Most people's definition of prayer rests on a theistic definition of God. God is perceived to be like the king, or perhaps one's boss, or even one's parent that is God is an external figure, who has great authority. So prayer is perceived of as an activity directed to an external figure, who possesses a supernatural power not available to the one who is doing the praying. Prayer then becomes a request from the powerless to the powerful, asking the powerful one to act in such a way as to do for the petitioner what the petitioner cannot do for himself or herself and yet what the petitioner wants to be accomplished. With that 
definition, the activity of praise, which is so frequently coupled with prayer, becomes little more than manipulative flattery.

At rock bottom, though it is disguised by pious words and phrases, prayer has become a request for the desires of the one praying to achieve his or her will, not the will of God. Perhaps in prayer to a theistic deity, there is an assumption that the will of the one praying and the will of God have become identical. If that is so, then prayer becomes an activity where the human being tells the divine one how to act. In this definition, prayer is finally idolatry, the attempt to impose the will of the human onto the divine. It is the idolatry of turning God into one who will do as I say. It is based on the assumption that I am superior to God, that I know what is best. It also assumes that the divine is a separate entity, not necessarily in touch with the human, except through miraculous intervention.

Someone has described this kind of prayer as "letters to a divine Santa Claus."

"Dear God,

I have been a good boy or a good girl. I have earned a reward. Please do the following for me.

I will leave you a present under the Christmas tree.

Love,

Juan or Maria or Raoul.”

That may be a characterization that some will find offensive, especially if it raises to consciousness the way those who are offended pray, but judging from the questions I receive, it is not an inaccurate characterization. Life is so filled with tragedy, sickness and pain that deep down we know that this kind of praying is delusional. Instead of facing that fact, however, life's pain causes people to think that they must be so evil as to be deserving, not of God's blessing, but of God's wrath. 
Two experiences in my life, one professional and one personal, brought me out of this theistic prayer pattern and into a very different understanding of prayer. I share both of them with you.

One occurred after I had transferred from being a priest in a town in Central Virginia to serve a church in Richmond, the capital of Virginia. A call came to me from a woman with whom I had worked closely in my former location. She was about 8 years older than I, married to a country doctor and the mother of three young children. She called to tell me that she was a patient in a university hospital about an hour's drive from Richmond. "I really need to talk to you," she said. "What is wrong, Cornelia?" I enquired, feeling her anxiety. She said she would rather not talk about it on the telephone, but hoped I could come up to see her as soon as possible. I did, the next day. When I stepped into her hospital room, she looked as lovely as she always had, but the sparkle of her smile was gone. I sat down beside her bed and she began to relate her story.

She had developed a cough and paid little attention to it, but it persisted far too long and her doctor husband finally insisted that it needed to be checked out. An appointment was made, tests were run and a devastating diagnosis was announced. She had a virulent form of cancer that was not curable. The statistics suggested that she had less than six months to live. After getting over the shock of her news, I asked her to tell me what her feelings were. She did. How could her husband continue to practice without her? He was a country doctor who made house calls all over that mountainous region and was called out by his patients at all hours of the night. He could not do what he did, without knowing that she was at home with the children. She talked about what it meant to know that she would never see her children graduate from high school or college. She would never know their partners in life, their career paths or her grandchildren. She talked out of the realization that her life would be so short, that her death would mark each member of her primary family in a very painful way. She talked about the meaning her death would have for her elderly parents. It was the most deeply honest conversation of which I had ever been a part. When one crosses the boundary 
between life and death with another person, all facades are dropped, all pretensions are surrendered. In that place two people relate with radical honesty. Cornelia and I ranged over the story of her life, her hopes and fears for almost three hours. It was as if time stood still, so deep was this communication.

When the time came that I had to leave to return home, I shifted gears and became more of a professional priest than a friend. I suppose I had the need to do something to relieve my own anxiety. So I said: “Cornelia, may I pray with you?” She did not object. If I had a need to pray, she was pleased to be able to accommodate me. So I took her hand, laid my hand on her head and prayed the prayer that seemed to me to be appropriate to these circumstances. It was the stringing together of a series of pious clichés which I had learned to do in my priesthood. When the prayer ended, I left for the hour's drive back to my home, promising to see her again.

On that drive home, I processed my experience. It had been a profound meeting of two people that crossed the boundary between life and death. The prayer at the end, however, had detracted notably from the experience. Which was the true prayer in that meeting, I asked? Was it the conversation that was so deep and so life giving? Or was it the words uttered before I left? Which of the two had expanded life and which had diminished life? Which one expanded love and which one suppressed love? Which one called both of us into a deeper sense of who we are, and which made us less human? Clearly the answer to these questions was the conversation not the words of prayer, so prayer began to be expanded in its meaning. Saying prayers was not the same as praying. I wrote the first book of my career out of that experience. It was entitled Honest Prayer. From that moment on, prayer became for me not something I said, but something I lived. That is a distinction we all must make before we try to define prayer.

The second experience came to me in the early 1980's when my first wife, her name was Joan, received a cancer diagnosis and the prognosis that she had 
"less than two years to live." The news became public almost as soon as I received it, for there is greatly diminished privacy when one is in public life. Because I was the bishop, well-known in the state of New Jersey and thus socially prominent, prayer groups were organized throughout the state on our behalf. Some were Episcopal prayer groups, some were Roman Catholic prayer groups and some were ecumenical prayer groups. Numerous people wrote to assure me of their prayers. I appreciated all of their gestures for they communicated people's love and concern for me and for my wife. When my wife exceeded the prediction and lived into her third year since the diagnosis, these prayer groups and individuals began to take credit for her longevity. "Our prayers are keeping her alive," they wrote. "God is answering our prayers." It seemed quite clear to them. My wife did live six and a half years from diagnosis to death, for which I was grateful, but I could not help but wonder about what kind of God it was to whom these gracious people were praying. Would those prayers have been offered for my wife, if I had not been well known, presumably successful and socially prominent? I thought to myself: suppose a garbage worker in the inner city of one of America's poorest cities had a wife who had received a cancer diagnosis. Would it not be true that few people outside her immediate family would have known about it. Would God have allowed her to live a shorter time, to die a more painful death because hordes of people did not pray for her? Would God reward my wife with greater longevity because I was prominent and well known? Does God validate social status? If I thought that for a moment, God would become so immoral that I would immediately cease to believe in God. Prayer, therefore, cannot be cumulative in its power and effectiveness. God cannot reward those who have achieved human status.

So what is prayer? It is not the petitions of human being to a theistic God above the sky to intervene in human history in the life of the one praying. Prayer is rather the developing awareness that God works through the life, love and being of us all. Prayer is present in every act which enhances life, which enables pain to be shared or courage to be found. Prayer is experiencing the presence of God that binds us to one another. Prayer is that activity that drives us to recognize in the 
words of St. Francis, that it "is in giving that we receive." Prayer is more present in the life we live than in the words we say. That is why St. Paul could exhort us to "pray without ceasing." That does not mean that we are to say prayers without ceasing. It means that we are to live our lives as a prayer, to walk into tragedy and pain knowing that we do not walk alone. It is to know and to understand that we can be the lives through which the divine enters the human. Prayer is the recognition that we live in God, who is the Source of our life, the Source of our love and the Ground of our Being. That is finally all that we can say about it. Prayer is something we live far more than something we do.

\section{Thesis n. 11}

"The hope for life after death must be separated forever from the behaviorcontrol morality of reward and punishment. The church must abandon, therefore, its reliance on guilt as a motivator of behavior."

God is so often perceived in Christian liturgy as the all-seeing, all-knowing judge, who is ready to pronounce a sentence on the basis of our behavior.

This God is believed to keep record books on our deeds up-to-date, which will determine our ultimate destination, that is, whether we will be with the saints in glory or with the rejected suffering in the fires of hell. It is very hard to believe in such a God once we embrace the dimensions of the universe. Where does this allseeing God live? Is it above the earth? Well, that would put God somewhere between the sun and the planet earth. Is God above our solar system? Well, that would locate God somewhere inside our galaxy. Is God above our galaxy? Well, that would locate God in galactic space. Is God beyond the universe? Well, that would locate God so far away that it would be hard to believe that the hairs of our heads are numbered and known. That image of God fitted a pre-modern world view. It does not fit ours. 
There are still other problems with this systemic understanding of God as the judge of our guilt and misdeeds on which presumably our eternal destiny will be determined. In the $19^{\text {th }}$ century human beings began to embrace the fact that there is a deep socialized component in human behavior. No two human beings are born equal. On what basis then are they to be judged individually? The disparities in the world's wealth are also enormous. Half of the world starves while the other half diets! There are vast differences in intellectual ability. Some are born brighter than others. There are vast differences in diet, education and opportunities. If one has plenty, the temptation to steal is almost irrelevant in that life. If one has nothing, if survival is a day to day struggle, the temptation to steal is so much greater. Can God judge anyone properly without taking into consideration these external circumstances? What parent is going to develop "moral values," while he or she watches his or her child malnourished, living in squalor with little opportunity ever to rise from the circumstances of that child's birth? Can judgment ever be just, if it is based only on individual human behavior?

In the $20^{\text {th }}$ century the Western world discovered how deep human psychological interdependence is. If one is an abused child, studies show that that child has a higher chance to grow into being an abusive adult. Does God judge this abusive adult behavior on a moralistic basis alone with no consideration being shown for the reasons this person grew up into being an abusive adult? Is the one who murders another, the only person who is guilty of that crime? To look at life on the basis of behavior and deeds alone is to affirm a radically unfair world. If that is the way God operates, then God is a radically unfair God.

In previous generations, parents may well have thought that the promise of a reward or the threat of a punishment was the proper way to raise a child. Especially if they thought of God as a judge above the sky or if they believed that reward and fear were proper ways to motivate a child. We now know so much more about human life that these patterns of thought have been largely abandoned. 
In 2009 I wrote a book about why I believe in life after death. It was published under the title: Eternal Life: A New Vision. Where I had to go to get to this new vision was reflected in the subtitle, which read: Beyond Religion, Beyond Theism, Beyond Heaven and Hell.

Eternal life, I believe, must be separated forever from the concepts of reward and punishment or heaven and hell. One might live a good and righteous life in response to the promise of reward or the threat of punishment, but a good and righteous life does not mean a whole and loving life. The basis upon which Christians have tended to judge human behavior is by holding before all people a standard by which we will be judged to be failures and then to make guilt the primary motivator of behavior. It does not work, it will not work. I know of no one who is ultimately helped by being made to feel guilty.

I know of many adults today who have been so frightened by the Church's portrayal of a God of judgment ready to punish the wicked that their lives are motivated not by love, but by fear. Is righteous behavior motivated by fear ever really righteous? If one is righteous because one is afraid not to be, does that bring wholeness? Is not such behavior still survival-oriented and self-centered?

Guilt as a motivator of goodness must go in the Church of the future. So must the fear of hell and the promise of heaven.

If John's gospel is correct, as I believe it is, the promise that Jesus extends to us is not to make us religious, moral or true believers. It is not to motivate us with guilt or with the promise of heaven or the threat of hell. It is, in the words John recorded for Jesus to say: "That you might have life and have it abundantly."

\section{Thesis n. 12}

"All human beings bear God's image and must be respected for the person that each of us is. Therefore, no external description of one's being, whether based 
on race, ethnicity, gender or sexual orientation, and no creed based on human words developed in the religion in which one is raised can properly be used as the basis for either rejection or discrimination."

That seems so obvious in theory, but has been so difficult for believers to live by in Christian history. There is in the human animal the same survival quest that marks all living things. Our fear of people who are different is born in that survival quest. How is it possible that anti-Semitism was the product of the religion based on the Jewish Jesus? How did Church leaders justify the wars, called the crusades, which were designed to kill the infidels, who just happened to be Muslims, living in what Christians called the Holy Land? How was it possible that Christians sought to keep their faith not only pure, but intact by burning at the stake anyone who disagreed with their creedal orthodoxy? On what ethical basis did some of the popes in history practice slavery against people of color? How did those Christians of European descent, who lived in that part of the United States known as "the Bible Belt," not only enslave those of African descent, but who also resisted giving that evil institution up in the bloodiest war in American history? When slavery was replaced with segregation, how was it possible for those claiming Christian identity to resist the downfall of segregation with fire hoses, police dogs and church bombings in which only little girls were killed? How was it possible that Christian leaders could define the female half of the human race as sub-human and not allow them to own property in their own names until the $19^{\text {th }}$ century, to attend universities and colleges until the $20^{\text {th }}$ century, and forbid them by law from voting, entering the professions, becoming ordained, entering politics and running for President of the United States until late in the $20^{\text {th }}$ century and early in the $21^{\text {st }}$ century? How was it possible for the Christian Church to continue to believe that homosexuality was a chosen life style caused by either mental sickness or moral depravity for fifty years after these definitions were obliterated and abandoned, the casualty of medical and scientific knowledge? All of these things are true and they have placed a stain on Christian history that will not be wiped from our memory easily. 
Jesus' admonition to love one's neighbor as one loves oneself seems not to have been heard by the church. The parable of the Good Samaritan which suggests that one must love the object of one's deepest fear and prejudice has been ignored. When the church sings hymns like "Just as I am without one Plea, O Lamb of God I come," it was most often nothing but a lie.

There is much in Christian history for which repentance is clearly required. The only way forward is to engage this act of penitence openly and honestly and to seek the forgiveness of our victims. White people complain about the black anger that white people themselves have created. Christians complain of Islamic anger that we have bred for centuries from the crusades in the $11^{\text {th }}$ to $13^{\text {th }}$ centuries, to our quest for the wealth of oil in the $20^{\text {th }}$ and $21^{\text {st }}$ century. Men are today fearful of women achieving power, and heterosexuals are fearful of homosexuals demanding marriage equality. All of these things are manifestations of religious ignorance and religious prejudice. A Christian Church that is morally compromised on so many issues of our history can never give moral leadership to the world.

\section{Conclusion}

In the baptism service of my Church, the candidates for baptism, the parents of the candidates and the candidates' sponsors are asked this question: "Will you seek Christ in all persons, loving your neighbor as yourself?" They answer: "We will with God's help." That must be the answer of the entire Christian Church if it hopes to live into the future.

These "The Twelve Theses" have now been laid before the Church. The future of Christianity will depend on how the Christian Church responds. 


\section{REFERENCES}

DARWIN, Charles. The Descent of Man. [1871]. London: Penguin Books. 2004. [First published: London: John Murray, 1871].

DARWIN, Charles. The Origin of Species by Means of Natural Selection. [1859]. New York: Modern Library, 1993. [Original: London: John Muray, 1859].

HARNACK, Adolf von. Mission et expansion du christianisme: aux trios premiers siecles. 4. ed. Paris: Cerf, 2004.

HUGO, Victor. Les Miserables. [1862]. New York : Simon \& Schuster, 2014

PASTERNAK, Boris. Dr. Zhivago. [1957]. New York : Knopf, 1991.

RSV Bible. The Revised Standard Version of the Bible. Available at:

<http://quod.lib.umich.edu/r/rsv/browse.html>. Access on: Sept 10, 2014.

SPONG, John Shelby. Why Christianity Must Change or Die. New York, NY: Harper Collins Publishers 1998.

STEINBECK, John. East of Eden. New York: Penguin Books, 2002..

XENOPHANES. Theology (critical), n. 5. Availabre at:

<http://home.wlu.edu/ mahonj/Ancient_Philosophers/Xenophanes.htm>. Access on:

Sept. 10, 2014. 